\title{
Tax Treatment of Artists' Charitable Contributions
}

The Internal Revenue Code was amended in 1969 to restrict sharply the tax deduction available to artists who donate their compositions to charity. ${ }^{1}$ Since that amendment, the number of charitable contributions by artists to museums and libraries has declined precipitously. ${ }^{2}$ Consequently, the public's ability to enjoy access to recent artistic and scholarly materials has suffered. ${ }^{3}$

Legislation in this area should be reevaluated to achieve the optimal accommodation of competing social objectives. This Note develops three policies that should influence the tax treatment of charitable contributions by creators of their compositions: the provision of an incentive to contribute; government subsidy of donations motivated

1. Tax Reform Act of 1969, Pub. L. No. 91-172, $\S 201($ a)(1)(B), 83 Stat. 487, I.R.C. $\$ 170(\mathrm{e})(1)$. For discussion of the 1969 amendment and of the prior law, see pp. 145-47 infra.

2. See, e.g., Letter from L. Quincy Mumford, Librarian of Congress, to Rep. Mills (Feb. 13, 1973), reprinted in Hearings on General Tax Reform Before the House Comm. on Ways and Means, 93d Cong., lst Sess. 6287-88 (1973) (contributions to Library of Congress of self-generated manuscripts declined from about 230 musical manuscripts and 179,000 literary manuscripts annually to zero donations in 1971 and 1972) [hearings hereinafter cited as 1973 Hearings]; Letter from Richard E. Oldenburg, Director, New York Museum of Modern Art, to John M. Martin, Chief Counsel, House Ways and Means Comm. (April 18, 1973), reprinted in 1973 Hearings, supra, at 6143 (gifts of works of art by their creators to Museum of Modern Art declined from 321 in three years prior to 1969 to 28 in three years after). This virtual cessation of charitable giving by creators has become a fact of life for museums and university libraries nationwide. See 1973 Hearings, supra, at 6110 (statement of Authors' League of America) (Columbia University reported $90 \%$ decline in number of authors' papers and manuscripts received in 1971); id. at 6138 (statement of American Library Association) (similar experience of other academic libraries). Evidence contained in a Library of Congress study suggests that the trend has not abated in more recent years. U.S. Library of Congress, LITERARX, MUsical, AND Artistic Donations to the Library of Concress, reprinted in 121 Cong. Rec. 10,191-92 (1975) [hereinafter cited as Library of Congress Study]; see 122 CoNG. RIc. 23,360 (1976) (Sen. Javits) (citing reports of continuing trend).

3. Some creators have begun placing their compositions "on deposit" without transferring title, see Library of CoNGRESS STUDY, supra note 2, at 10,192 (deposit practice unsatisfactory because recipients unwilling to organize material without assurance of full title); selling their compositions, which results in "dispersal of historically important materials among many private collectors, thereby making this material unavailable for future scholarship or making it very difficult for scholars to locate", see id.; or withholding their works entirely, possibly awaiting more favorable tax treatment, or intending to make a charitable bequest at death or to leave their compositions to their heirs as part of their estates, see $i d$. 
by charitable purposes but not those motivated solely by financial benefits; and consideration of horizontal equity and economic efficiency. Neither prior law, nor present law, nor recent legislative proposals are fully responsive to these criteria. This Note, however, proposes an amendment to the Internal Revenue Code that would further all three policy considerations.

\section{The Design and Impact of the 1969 Amendment}

Since 1917, taxpayers have been allowed a deduction from gross income for charitable contributions. ${ }^{4}$ From 1917 until 1969, contributions of appreciated property were deductible from gross income at the fair market value of the donated property. ${ }^{5}$ This fair market value rule provided donors of appreciated property with a deduction in the amount of basis plus unrealized appreciation, even though they had never been taxed on the unrealized appreciation. ${ }^{\circ}$

The fair market value rule, however, had two incidental effects that Congress considered unacceptable. First, some taxpayers could benefit more from contributing their property than from selling it; a taxpayer in a marginal tax bracket above fifty percent could receive a greater tax benefit from using the deduction to offset other highly taxed income than he could earn from the sale of the property, after paying the high taxes on the gain from the sale. ${ }^{7}$ Second, the fair market value rule

4. The charitable contributions deduction was first enacted by the War Revenue Act of 1917 , ch. $63, \S 1201(2), 40$ Stat. 300 (now I.R.C. $\S 170$ ). The deduction was enacted in response to concern that the increased tax rates legislated to finance World War I would decrease the amounts contributed to charitable organizations. See 55 Conc. REc. 6728-29 (1917) (remarks of Sen. Hollis and reprinted newspaper editorials). See generally C. KaHN, Personal Deductions in the Federal Income Tax 6-7, 46-47 (1960) (summarizing amendment's legislative history).

5. See Mansfield and Groves, Legal Aspects of Charitable Contributions of Appreciated Properly to Public Charities, in IV Research Papers Sponsored BY THE Commission on Private Philanthropy and Punlic Needs 2251, 2251-52 (1977) (summarizing positions of Treasury Department and Congress on issue of fair market value deduction between 1917 and 1969) [book hereinafter cited as FILER PAPERs].

6. For instance, if an artist painted a painting using materials costing $\$ 10$ and contributed it to a charitable organization when it was worth $\$ 100$, he received an itemized deduction from adjusted gross income of $\$ 100$. The $\$ 10$ paid for the painting was drawn from after-tax income; a tax had been paid when the money was earned. The $\$ 90$ in appreciation in value was never taxed, however, as the gain was never taken into income. If the painting were sold instead of donated, the $\$ 90$ would have been taxed as ordinary income.

7. Earned income is taxed at a maximum rate of $50 \%$, I.R.C. $\$ 1348$, (provision enacted in Tax Reform Act of 1969), but unearned income is taxed at rates up to $70 \%$, I.R.C. $\$ 1$. In the example in note 6 supra, if the taxpayer were in the $70 \%$ marginal tax bracket, and he sold the painting, he would earn $\$ 55(\$ 100-.5(\$ 90))$ after taxes on his initial in- 
favored gifts of appreciated property over gifts of cash; cash donations were drawn from income subject to taxation, while any appreciation of contributed property escaped taxation. ${ }^{8}$

To eliminate these effects, Congress amended the Internal Revenue Code in 1969 so that charitable contributions of ordinary income property, ${ }^{9}$ including creator-held creative compositions, ${ }^{10}$ generate a

vestment of $\$ 10$. However, if he contributed the painting to a qualifying charity, he would receive a deduction of $\$ 100$, which would offset taxes on other unearned income by $\$ 70$ $(.7 \times \$ 100)$. Thus a sale would yield only $\$ 45$ on the entire transaction $(\$ 55-\$ 10)$; the donation would benefit the taxpayer by $\$ 60(\$ 70-\$ 10)$. This example, like all examples in this Note, is simplified and ignores effects of the interaction of the maximum tax on earned income and the minimum tax on tax preference items, which alter the precise tax benefit of a $\operatorname{tax}$ deduction. This simplification assumes that taxpayers have an effective marginal tax rate of $70 \%$ and that they have substantially more unearned income than earned income. While very few taxpayers actually may be in this bracket, the Code should account for this situation even if it arises rarely in practice. See p. 163 infra.

In general, for any taxpayer in a tax bracket above 50\%, the fair market value rule could lead to a gift being more profitable than a sale whenever $m \geqslant \frac{C+.5 A}{C+A}$ where $m$ is the marginal tax rate, $\mathrm{C}$ is the cost or basis, and $\mathrm{A}$ is the amount of unrealized appreciation. As C/A approaches zero, profits from a gift, designated as $\pi_{g}$, will become greater than profits from a sale, $\pi_{s}$, as $\mathrm{m}$ becomes greater than .5 . As $\mathrm{C} / \mathrm{A}$ increases, $\mathrm{m}$ must increase for $\pi_{\mathrm{g}}$ to be greater than $\pi_{\mathrm{s}}$. That is, if $\mathrm{C} / \mathrm{A}=.25, \pi_{\mathrm{g}}>\pi_{\mathrm{s}}$ only when $\mathrm{m}>.6$. When $C / A \geqslant 2 / 3$, it is impossible for $\pi_{g}$ to be greater than $\pi_{s}$, because $m$ cannot be greater than .7 under present income tax rates.

8. For example, compare the gift of a painting worth $\$ 100$ at time of gift, with a basis to the donor of $\$ 10$, with the contribution of $\$ 100$ in cash. The former donation generated a $\$ 100$ deduction without the imposition of any tax on the $\$ 90$ of appreciation. The latter gift also entitled the donor to a $\$ 100$ deduction, but this deduction offset the income tax that was already paid when the $\$ 100$ was earned. If the two taxpayers were in the maximum $50 \%$ bracket on earned income, the first individual earned $\$ 20$ originally, of which $\$ 10$ remained after taxes to purchase the materials for the painting, which, when contributed, generated a $\$ 100$ deduction. The second taxpayer, however, had to earn $\$ 200$ before taxes to retain $\$ 100$ to donate to generate a $\$ 100$ deduction.

9. "Ordinary income property" is defined as property with appreciation that would not have been a long-term capital gain if the property had been sold for its fair market value by the donor at the time of the gift. See Treas. Reg. $\$ 1.170 A-4(b)(1)(1972)$.

10. See I.R.C. $\$ 1221$ (defining "capital asset" specifically to exclude "a copyright, a literary, musical, or artistic composition, a letter or memorandum, or similar property, held by . . . a taxpayer whose personal efforts created such property"). When Congress sought to limit deductions for contributions of creative compositions, it employed the distinction between capital gains and ordinary income by permitting only the basis of ordinary income property to be deducted. When Congress decided to restrict deductions for gifts of other similar types of property, the capital gains distinction was used again. Thus, $\$ 514(\mathrm{a})$ of the Tax Reform Act of 1969 added letters, memoranda, and papers to the list of exclusions from capital asset status. Government publications received by the taxpayer at no or reduced charge were excluded from the definition of a capital asset by $\$ 2132$ of the Tax Reform Act of 1976, I.R.C. $\$ 1221(6)$. Finally, special rules for determining allowable deductions for contributions of inventory, which is ordinary income property under I.R.C. $\$ 1221(1)$, were provided by $\$ 2135$ of the 1976 Act, I.R.C. $\$ 170$ (c)(3). The proposal recommended in this Note also uses the capital gains distinction to reform the tax treatment of artists' donations. See pp. 164-67 infra. 
deduction in the amount of only the basis. ${ }^{11}$ Thus, since 1969, charitable contributions by creators of their compositions have been deductible only to the extent of the cost of the materials used to create the composition. ${ }^{12}$

This rule was responsive to the two concerns that motivated the 1969 amendments: it is now impossible for a creator to benefit more by contributing his composition than by selling it, ${ }^{13}$ and the tax advantages enjoyed by creators donating appreciated property rather than cash have been eliminated. ${ }^{14}$ However, the 1969 amendment has had

11. Tax Reform Act of 1969, Pub. L. No. 91-172, $\$ 201(a)(1)(B), 83$ Stat. 487, I.R.C. $\$ 170(e)(1)$. The House version of the bill would have limited the charitable contributions deduction to the cost of the donated property for the following five types of property: property contributed to private foundations other than private operating foundations; ordinary income property; tangible personal property; future property interests; and bargain-sale property. See H.R. REP. No. 413, 91st Cong., 1st Sess. 54-55 (1969), reprinted in [1969] U.S. Code Cong. \& AD. News 1700-01.

The Ways and Means Committee Report articulated two reasons for applying the cost deduction rule to contributions of creator-held appreciated property: the "double deduction" nature of a deduction for appreciation that was never taxed, and the difficulty of valuing art work coupled with the tendency of artists to overvalue their own work. Id. at 53-55, [1969] U.S. Code Cong. \& Ad. NEws at 1700-01.

The Senate version of the charitable contributions section of the bill was less sweeping. The Senate Finance Committee deleted the House provisions that would have reduced the allowable deductions for contributions of appreciated tangible personal property, future interests in appreciated property, and bargain-sale property, justifying the deletion by pointing to the provisions' potentially adverse impact on charitable giving and failure to solve the valuation problem. See S. REP. No. 552, 91st Cong., 1st Sess. 82 (1969), reprinted in [1969] U.S. Code Conc. \& AD. News 2111.

Contributed property is placed in one of three categories for tax purposes: ordinary income property; unrelated-use tangible personal property; and, intangible personal, real, and related-use tangible personal property. I.R.C. $\$ 170(e)(1)$. Unrelated-use property is property that the donee puts to a use unrelated to the purpose constituting the basis of the donee's tax exemption. See Treas. Reg. \$ I.170A-4(b)(3)(1) (1972). The 1969 amendment concerns contributions only of appreciated property. Cash contributions were not affected and remain fully deductible.

12. It is unclear why the special tax advantages for gifts of creator-held property were eliminated, while identical benefits for contributors of other types of appreciated property were either limited less severely-in the case of unrelated-use tangible personal propertyor left intact-in the case of real, intangible personal, and related-use tangible personal property. This harsh treatment of artists seems to stem from doubts regarding the value of art in general and from concern about the danger of fraudulent valuation of contributions. When asked to explain the differential treatment accorded ordinary income property contributions and other types of gifts, Rep. Mills replied, "Paintings and other art objects are very hard to value. As a result very high values are placed on paintings which cost the person very little. Who is to say how much the painting is really worth?" 115 CoNG. REC. 22,571 (1969). But see note 39 infra (valuation of art no longer problem).

13. This can be proved as follows: $\pi_{\mathrm{s}}=\mathrm{A}(1-\mathrm{m})$, and $\pi_{\mathrm{g}}=\mathrm{C}(\mathrm{m}-1)$; if $\mathrm{m}<1$, then $\pi_{\mathrm{s}}>0$, and $\pi_{5}<0$. Therefore, $\pi_{s}>\pi_{g}$. See note 7 supra.

14. Since 1969 , the artist who paints a painting with $\$ 10$ worth of materials and contributes it when it has a market value of $\$ 100$ receives a deduction of $\$ 10$. If he is in the $70 \%$ bracket, this offsets his taxes on unearned income by $\$ 7$, netting him a loss of $\$ 3$ after subtracting the $\$ 10$ cost. The fact that his painting has appreciated in value 
other, undesirable effects. Creators' contributions of their compositions now are treated quite differently from gifts of similar compositions by collectors; a composition in the hands of its creator is ordinary income property, deductible only up to its basis, while the identical composition in the possession of a collector is deductible up to its fair market value. ${ }^{15}$ This restriction on deductions for contributions of creatorheld compositions has resulted in a virtual cessation of contributions by living creators of their works. ${ }^{16}$ Some artists have begun to sell their works or to withhold them indefinitely. ${ }^{17}$ These compositions are at least temporarily, and possibly permanently, inaccessible to the public.

\section{Three Policies to Guide a New Rule}

The 1969 amendment responded to two problems generated by the fair market value rule for charitable contributions by creators of their compositions. But the restricted deduction allowed since 1969 itself has spawned serious deficiencies. Before yet another piece of legislation is proposed, the basic questions underlying this area of the Code should be reconsidered. From an analysis that focuses on the nature of creative compositions, three policies emerge that respond to these underlying questions: the government should provide a tax incentive to creators for charitable contributions of their creative property; this incentive should be available only to creators with charitable motivations; and,

secures him no tax benefits; he could have achieved the same $\$ 7$ reduction in taxes by contributing $\$ 10$ in cash. Moreover, if this artist had sold the property at its market value of $\$ 100$, paid a maximum $50 \%$ tax on the $\$ 90$ gain, and donated his $\$ 100$ pre-tax revenue to a charity, he would have received a tax benefit of $\$ 25(.7(\$ 100)-.5(\$ 100-\$ 10))$ and earned a $\$ 15$ profit, subtracting his costs. Thus, not only is there not a tax advantage to contributing appreciated property over cash, but there may be a sizable disadvantage to giving property.

15. The limitation on deductions for contributions of ordinary income property to the basis of the property creates a vast disparity, because typically the ratio of cost to market value for creative compositions of any significant market value is very small. In the case of a painter, the basis is the cost of materials used in creating a painting. Because the greatest portion of this cost is often the frame, the painter receives almost the same tax benefit for contributing an empty frame as he would for contributing a valuable painting. See 1973 Hearings, supra note 2, at 6022 (testimony of John B. Hightower, President, Associated Councils of the Arts) (estimating cost of oils and canvas for typical painting at $\$ 45$ ); id. at 6128 (letter from Glenn A. Anderson, Executive Director, Alford House, Anderson Fine Arts Center, Anderson, Indiana, to the Artists Equity Association of New York) (estimating materials cost for Robert Motherwell collage at $\$ .50$ ); id. at 6118 (testimony of Elias Newman, Chairman, Conference of American Artists) (estimating cost of Rembrandt ink drawing at \$.04). For a musical or literary composer, the deduction would normally cover only the cost of pencil and paper. See id. at 6107 (testimony of Herman Wouk) (estimating cost of 5,000-page Wouk manuscript at $\$ 30-\$ 40$ ).

16. See note 2 supra.

17. See note 3 supra. 
any such tax provision should reflect considerations of horizontal equity and economic efficiency.

\section{A. Provision of an Incentive}

The need for government intervention to increase public access to creative compositions stems from the private market's inability to provide an optimal level of access to these artistic goods. Identification of the proper mode of government intervention follows from an analysis of the distribution among individuals of preferences for creative goods.

\section{The Need for Government Intervention}

Creative compositions are social goods; that is, they are goods that can yield benefits not reserved to the single individual who owns them. ${ }^{18}$ If a painting or historical work is made available to the public, many people other than the owner can enjoy it. Certain charitable organizations $^{10}$ such as government or private nonprofit museums and

18. Social goods are also called "public goods" or "collective goods" by economists. The term "social good" is used throughout this Note, because the term "public good" confuses the good itself with a frequent source of its provision. Because social goods can be provided by both public and private institutions, the term "public good" is misleading. See B. Weisbrod, The Voluntary Nonprofit Sector 73 n.18 (1977). Two prominent public finance economists describe clean air as a social good as follows:

If I consume a hamburger or wear a pair of shoes, these particular products will not be available to other individuals. My and their consumption stand in a rival relationship. This is the situation with private goods. But now consider measures to reduce air pollution. If a given air quality improvement is obtained, the resulting gain will be available to all who breathe. In other words, consumption of such products by various individuals is not "rival" in the sense that one's partaking of benefits does not reduce the benefits available to others.

R. Musgrave \& P. Musgrave, Public Finance in Theory and Practice 7 (2d ed. 1976). Clean air is an example of a social good that is both non-rival and non-excludable.

The term "social good" also is applied to goods that are non-rival but excludable. Creative compositions, for example, are excludable-enjoyment of the benefits can be restricted to those who pay an admission fee-but non-rival; in this case, exclusion is feasible, but inefficient. See id. at 51-53.

It is difficult to prove that any goods are pure social goods. See id. at $56-59$ (discussing theory of "mixed goods" with both social and private features). Yet many goods seem to have significant social-good aspects. Even though the benefits of an elementary and secondary education are largely internalized to the student there are also substantial benefits to others. See Friedman, The Role of Government in Education, in EcoNomics and the Public Interest 124 (R. Solo ed. 1955), reprinted in Perspectives on the EcoNomics of Education 133 (C. Benson ed. 1963) (education has "neighborhood effect" in promoting a stable and democratic society). See generally $\mathbf{R}$. Musgrave, The Theory of Public Finance 9-12, 43-44 (1959); R. MusGrave \& P. MusGrave, supra, at 7-9, 49-59; Samuelson, The Pure Theory of Public Expenditures, 36 REv. Econ. \& STATISTICs 387 (1954).

19. The term "charitable organization" is used in this Note to refer to an organization qualified to receive tax-deductible charitable contributions. The organizations that com- 


\section{libraries attempt to satisfy the broad demand for the use and enjoy- ment of creative compositions by providing public access to musical, literary, scientific, historical, and artistic works. ${ }^{20}$}

prise this category are those "operated exclusively for religious, charitable, scientific, literary, or educational purposes, or to foster ... amateur sports competition . . . or for the prevention of cruelty to children or animals." I.R.C. $\$ 170(c)(2)(B)$. But see I.R.C. \$ 501(c)(3) (tracking I.R.C. $\$ 170(c)(2)(B)$ but adding organizations "testing for public safety"). The use of the term "charitable organization" in this Note is intended to connote any among the class of $\S 170(c)(2)$ or $\$ 501(c)(3)$ organizations. See Treas. Reg. $\$ 1.501$ (c)(3)-1(d)(2) (1960) (discussion of narrow and broad scopes of meaning of "charitable organizations").

The fact that charitable organizations, like governments, produce social goods distinguishes them from private market organizations: it explains their nonprofit status and their reliance on subsidies such as tax-exemption and private and government contributions, rather than on admission charges, as the principal means of financial support. See B. WeIsBrod, supra note 18 , at 1-3 (charitable organizations produce social goods); id. at 93-158 (attempt to separate production of social goods and private goods in various charitable organizations).

20. In the case of creative compositions, only when such compositions are accessible to the public is their potential as a social good realized. Thus, throughout this Note, the "amount of production" or "Ievel of output" of social goods refers to the quantity of public access to these compositions. The focus of attention is the shifting of creative compositions from private to public uses. The total quantity of new creative work produced in the country is not discussed. Since the elasticity of supply of artistic goods is probably very low, it is unlikely that the total quantity will be significantly affected by changes in incentives to donate. Creative compositions are of two basic types: works of visual art; and literary and musical compositions, letters, memoranda, and papers. The two types are treated similarly by I.R.C. $\$ 1221(3)$. The two differ, however, in that the former category consists of property that is the creator's intended output, while the latter group consists of incidental by-products of the creator's efforts. Thus, an author may write a novel and sell the rights to a publisher; his manuscript and notes are incidental. Aside from speculative demand for a creator's papers, this latter type of property is not normally considered in private demand, except for an occasional idiosyncratic hobbyist or snob. Investment purpose is excluded from private demand because it does not represent final demand-consumption-but rather demand based on anticipation of some other future demand. Therefore, it is reasonable to conclude that literary, musical, and historical compositions have minimal private-good aspects.

Artistic compositions, however, have a more clearly defined private-good component. There is a flourishing private market in art, not all of which can be viewed as speculation. The remaining private demand cannot be characterized as due solely to snobs or obscure collectors. Copies of works of art do not meet the purposes of the originals, while copies of novels do. Thus, while it is not common for an individual to purchase the manuscript of, and right of reproduction to, a novel for his own enjoyment, it is normal for an art collector to do the equivalent.

Access to art may be rival in another sense as well. If the admission of an additional individual to a museum imposes no additional costs, the admission is warranted. Often, however, an additional admission will impose a crowding cost on the other viewers. In this case the composition has ceased to become a pure public good as consumption is, to a degree, rival. For the effects of this complication, see R. Musgrave \& P. Muscrave, supra note 18, at 615-22; Buchanan, An Economic Theory of Clubs, 32 Economica 1 (1965).

It is relatively easy to separate the private- and social-goods aspects of literary compositions. The former demand is met through paperback and hardcover book sales, while the latter is satisfied by research libraries. Public libraries also provide access to general, nonresearch materials seemingly closer to private goods, but that can be cxplained as an 
Because the benefits derived from social goods are available to all individuals once they have been provided to the public by a single individual, the private market system does not produce the optimal amount of social goods. The market system produces the optimal level of private goods because consumers know that if they do not pay for a particular good, they will not be able to consume it; therefore, each consumer demands goods up to the point at which the marginal benefits to him no longer exceed the marginal costs of an additional unit. ${ }^{21}$ However, social goods yield benefits to individuals other than the purchaser. ${ }^{22}$ Thus, the total marginal benefit to society will be greater than the individual purchaser's marginal benefit. When each individual equates his marginal benefit with his marginal cost to determine the quantity he purchases, he ignores "external" benefits, that is, the benefits that flow to other people. The optimal quantity of a social good, however, is the amount at which the total marginal benefit-not the individual marginal benefit-equals marginal cost. ${ }^{23}$ Because the private market recognizes only individual benefits, the market system will generate a deficient level of social goods. ${ }^{24}$ This suboptimal level

educational function. See B. WeISBROD, supra note 18, at 60-61, 152-56. While art may not be as pure a social good as are other types of compositions, the social-good component of art seems dominant.

The role of charitable organizations that provide public access to creative compositions is conceived in this Note as primarily the production of social goods. Two alternative functions exist. First, charitable organizations may be viewed as distribution-oriented, rather than efficiency-motivated, institutions. In this view, individuals support artistic institutions not because they value the output of those organizations for themselves, but because they wish to increase the utility of others who may desire access to artistic compositions. Although economists have traditionally treated such distributional concerns as distinct from the micro-economic analysis used in this Note, distributional preferences have recently begun to be analyzed within the efficiency framework as another socialgoods preference. See, e.g., Hochman \& Rodgers, Pareto Optimal Redistribution, 59 AM. ECoN. REv, 542 (1969). The second alternative approach, not so easily integrated with this analysis, is that individuals contribute to artistic institutions to change, not to satisfy, the preferences of other individuals. If this motivation can be considered the mere provision of information, the analysis is secure. In any other case, the view threatens the economist's assumption of "consumer sovereignty," a necessary element of the demand analysis used in this Note.

21. This point is the equilibrium point, where supply is equal to demand. See $\mathbf{R}$. Dorfman, Prices and Markets 21-25, $107-42$ (3d ed. 1978) (explaining consumer demand theory).

22. See A. Pigou, The Economics of Welfare 149-79 (1920) (discussing "externalities," the divergence of private and social costs and benefits); Mishan, The Postwar Literature on Externalities: An Interpretative Essay, 9 J. Econ. LITERATure 1 (1971) (reviewing literature on externalities and discussing relationship between social goods and externalities).

23. See R. Musgrave \& P. Musgrave, supra note 18, at 53-55 (comparing optimal production of private goods and social goods).

24. A simple graphic illustration may be helpful. In the case of a social good, in. dividual benefits may be summed to represent a demand schedule, such as $D_{1}-D_{1}$ in 
should be remedied by the government if it can do so at a cost lower than that sustained as a result of the failure of the private market system. $^{25}$

Figure 1, when the true total benefits, including external benefits of the good, would really be represented by $D_{c}-D_{c}$. In this case, the market mechanism will lead to the point $E_{1}$, where quantity produced is $q_{1}$ and price is $p_{1}$.

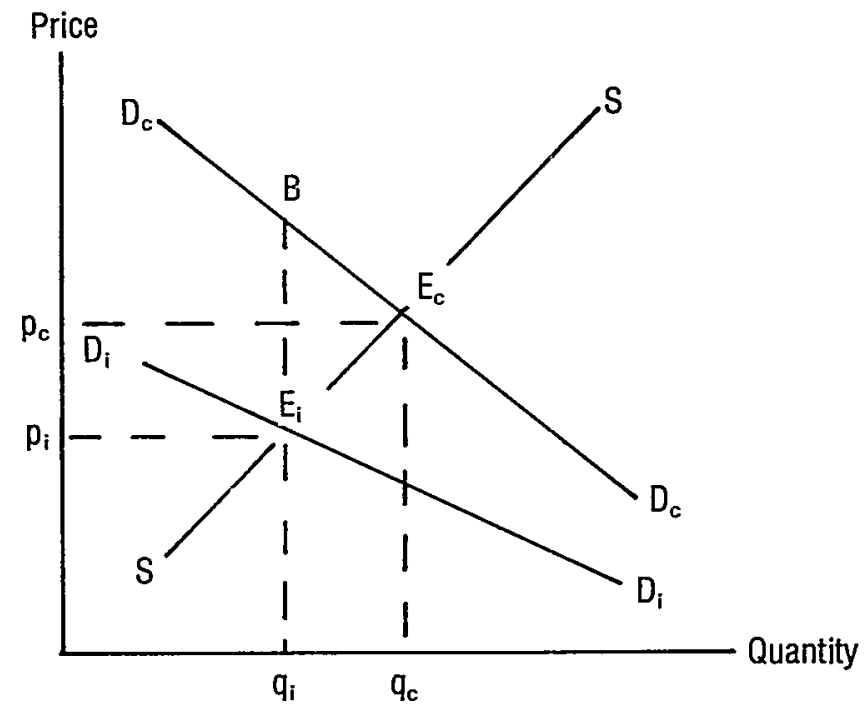

Figure 1

However, if the external demand, which is not reflected in the private market system, is taken into account, the optimal point of production is $E_{c}$, with price $p_{c}$ and quantity $q_{c}$. The difference between $q_{c}$ and $q_{i}$ represents the shortfall from the optimal level of production. See R. Musgrave \& P. Musgrave, supra note 18, at 56-57 (benefit externalities from private consumption).

Where the number of individuals is large, the individual benefits may be so dominated by the external benefits that the market does not produce any of the social good. See id. at 8 .

Since the benefits are available to all, consumers will not voluntarily offer payments to the suppliers of social goods. Each will benefit as much from the consumption of others as from his or her own, and with thousands or millions of other consumers present, the individual's payment is only an insignificant part of the total. Hence, no voluntary payment is made. The linkage between producer and consumer is broken. Id. This phenomenon, called the "free rider" problem, is discussed in J. Buchanan, ThE Demand and Supply of Public Goods 77-99 (1968).

25. Because of the existence of "market failure," the optimal solution is not possible and a "second-best" situation exists. See T. Scitovsky, Welfare and Competition 481 (1971); Lipsey \& Lancaster, The General Theory of Second Best, 24 Rev. Econ. Srud. 11, 11-18 (1956). Government intervention will have costs, as will a laissez-faire policy: for example, administrative costs, costs of incorrectly calculating preferences for social goods, and costs of distortions caused by the government's taxing system. Only if these costs are less than the costs imposed by the market failure, see note 24 supra (in Figure 1, the costs are represented by the triangle $\mathrm{BE}_{\mathrm{l}} \mathrm{E}_{\mathrm{c}}$ ), is intervention warranted. This point is repeated 


\section{The Form of Government Intervention}

The most common form of government intervention in the production of social goods is through direct provision of the goods. ${ }^{26}$ Direct government provision of a social good would lead to the optimal level of output if the government could provide the good in the amount at which the sum of individuals' marginal benefits equals marginal costs. Direct provision under any other rule generates a suboptimal level of the social good. ${ }^{27}$ Analysis of direct provision as a mode of intervention must focus on whether decisionmaking mechanisms exist that would lead the government to provide the optimal level of social goods.

Most models of government decisionmaking predict that the government cannot provide social goods in accord with the optimal marginal benefit rule. ${ }^{28}$ One simple method of government decisionmaking is majority voting. Under majority voting, if there are no significant opportunities to influence the vote by coalitions or logrolling, ${ }^{29}$ the level

frequently in Coase, The Problem of Social Cost, 3 J.L. \& EcoN. 1 (1960). If the intervention is not justified on resource cost grounds, the laissez-faire allocation may be the second-best solution, and government intervention may lead to a less, rather than a more, efficient allocation of resources. See T. Scitovsky, supra, at 480-86.

26. For example, the federal government directly provides public access to creative compositions, primarily through budgetary funding of the National Endowment for the Arts, the National Endowment for the Humanities, the Smithsonian Institution, and the Library of Congress.

27. See Tullock, Problems of Majority Voting, 67 J. Political Econ. 571, 572 (1959) (defects in direct provision models).

28. According to traditional analysis, there is no effective way for the government to discover each individual's marginal benefits. See R. MusGrave \& P. MusGrave, supra note 18, at 74-77. Recently, however, economists have suggested ways of obtaining this information. One proposal involves use of a special taxing and voting procedure. See Tideman \& Tullock, A New and Superior Process for Making Public Choices, 84 J. Polirical Econ. 1145 (1976) (Clarke tax mechanism may lead to accurate revelation of preferences). The preference revelation mechanism proposed by Tideman and Tullock would require all voters to express their preferences for each of such a large number of goods-here, the entire spectrum of creative compositions-that the system would be administratively infeasible. Another approach suggests that individuals choose among bundles of social goods provided by different local jurisdictions when they select their residence. See Tir, sout, A Pure Theory of Local Government Expenditures, 64 J. Political Econ. 416 (1956) (individual place-of-residence decisions may reflect demand for different levels of social goods). The Tiebout hypothesis applies only to goods with social-goods externalities that are limited geographically and that are, therefore, provided by local governments. Because creative compositions are nationally available social goods, encouraging production is a federal, rather than solely a local, issue. Barring the consideration of immigration and emigration as a preference revelation mechanism, the Tiebout hypothesis cannot be applied to social goods that are provided on a nationwide basis.

29. A simple majority voting rule assumes that each individual has one vote to be exercised individually on an issue, in isolation from other issues (no logrolling) and other voters (no coalitions). Furthermore, it assumes that the cost of goods approved by the majority voting model will be borne equally by all individuals, regardless of how they voted.

The no-logrolling assumption is reasonable given the congressional process for determining the level of direct provision of public access to creative compositions. One 
of government production of a social good is determined by the preferences of the median voter, who has distributed on each side of him an equal number of voters who prefer either more or less of the good. ${ }^{30}$ The median voter chooses the level of output for society by equating his marginal taxes (his proportionate share of the cost of marginal output) with his marginal benefits. Unless tastes are perfectly homogeneous, some voters will desire a greater level of production and

model of congressional logrolling suggests that Congressmen array themselves on committees providing social goods that their constituents demand disproportionately highly. See W. Niskanen, Bureaucracy and Representative Government 138-46 (1971). For example, the Congressmen whose constituents demand great amounts of national defense sit on the committees setting the level of direct provision of defense, and so forth for each social good. Direct provision of public access to creative compositions, however, through funding of the National Endowment for the Arts and the National Endowment for the Humanities, is primarily determined by the Interior Subcommittee of the House Appropriations Committee. Budgeting for public access to creative compositions accounts for less than $2 \%$ of the funds appropriated by this subcommittee. See H. REP. No. 392, 95th Cong., 1st Sess. 14, 107 (1977). It is likely, therefore, that the Congressmen on the subcommittee are logrolling for social goods other than public access to creative compositions.

30. This simple majority voting result is sometimes known as the median voter rule. See Steiner, The Public Sector and the Public Interest, in Public Expenditures ANd Policy Analysis 46 (R. Haveman \& J. Margolis eds. 1970).

This analysis applies technically only to homogeneous goods. Because the set of all creative compositions is not a single homogeneous good, each differentiated type of composition should be considered individually. The under-production outcome will obtain for each good that has a downward-skewed demand distribution, albeit to a different degree depending on the relative skewness of the distributions.

Although differentiated goods technically cannot be aggregated, it is appropriate for convenience to treat public access to each charitable organization as a distinct good, consisting of the portfolio of the museum or library. Then, instead of examining the optimality of public access to discrete compositions, the analysis aggregates to the level of each creative mix presented to the public by a charitable organization.

Because of the diversity among creative compositions, a vote on each particular type of composition wuuld not be administratively feasible. Yet if a vote simply determined the total amount of money to be spent on increased public access, under the government provision model some decision would have to be made as to how the funds should be allocated among various types of creative compositions. The more democratic the allocation process, the greater the restraint on diversity, minority expression, and innovation would be. On the other hand, the more the allocation mechanism is insulated from majoritarian tastes, the more likely the allocation would be biased toward the particular preferences of the officials distributing the funds.

The major source of direct provision of creative compositions by the government is the National Endowment for the Arts (NEA) and the National Endowment for the Humanities (NEH). As predicted, each of these organizations has been criticized for being both too elitist and too popularistic. See, e.g., N.Y. Times, Feb. 9, 1975, $\$$ II, at 1, col. 4 (debate between Herbert Gans and Ernest van der Haag on NEA funding of "popular" versus "high" culture); Editorial, N.Y. Times, Dec. 25, 1977, $\S$ IV, at 10, col. I (art necessarily elitist; merit cannot be measured by voting). Complaints recently have become widespread that the arts bureaucracies have become overly politicized and too responsive to ethnic, geographic, and demographic concerns. See, e.g., N.Y. Times, Oct. 16, 1977, $\S$ II, at I, col. 4 (Joseph Duffey's selection as NEH head due to political motivations); N.Y. Times, Oct. 16, 1977, $\S$ II, at 36 , col. 1 (same criticism of Livingston Biddle, Jr.'s appointment as head of NEA); Editorial, N.Y. Times, Dec. 25, 1977, $\S$ IV, at 10, col. I (commenting on ethnic and geographical criteria for allocation of funds). 
others will prefer a lower output than is selected; only the median voter will be perfectly satisfied. Under the plausible assumption that the population's preferences for social goods such as creative compositions are skewed toward a lower level of output, ${ }^{31}$ the output selected by the median voter will always be less than the optimal output. ${ }^{32}$

31. This assumption will be satisfied if tastes are asymmetrically distributed in such a way that the median preference is Iower than the mean preference. This condition is almost certainly true for creative compositions. Although data on the distribution of preferences for creative compositions are thin, existing evidence supports the assumption. A survey of library use in New Jersey found that $54 \%$ of the sample had not been in a library in the year preceding the study, while $16 \%$ of the population used a library at Ieast once a month. N.Y. Times, April 11, 1976, $\$ \mathrm{XI}$, at 1, col. 7. Interpolation yields a mean use of roughly four times a year-obviously greater than the median use of zero times a year. This skewed distribution is apparent in other fields with estimated median attendance figures of zero. See N.Y. Times, Feb. 9, 1975, $\S$ II, at 1, col. 4 (Harris poll reported that only $49 \%$ of respondents ever attended art museums). More robust evidence is available for performing arts organizations, which do not provide creative compositions but which may exhibit similar preference patterns. See Fond Foundation, 2 The Finances of the Performing ArTs II (1974) (study found that $77 \%$ of population had not attended live ballet, theater, opera, or symphony performance in past year).

32. Assume there are three voters whose linear demand curves (represented by $D_{1}, D_{2}$, and $\mathrm{D}_{3}$ in Figure 2) for one particular type of social good are symmetrically distributed, parallel, and non-negative. In this case, the optimal output is at equilibrium point $\mathrm{E}_{0}$, where the social demand curve $D_{e}$, obtained by summing vertically $D_{1}, D_{2}$, and $D_{3}$, intersects $S$, the supply or marginal cost curve, assumed here to be horizontal. At this optimal allocation, price is $\overline{\mathbf{p}}$ and output is $\mathrm{q}_{0}$. The median voter rule equilibrates the median voter's preference with the share of the costs he bears, which is $1 / 3$ of $\vec{p}$ or $\frac{\bar{p}}{3}$, assuming proportional taxation. This equality is established at $E_{r}$, where output is $q_{r}$. Thus, the median voter rule generates an output of $q_{v}$, which is less than $q_{o}$, the optimal output. Therefore, the median-voter rule has generated a suboptimal level of production of the social good.

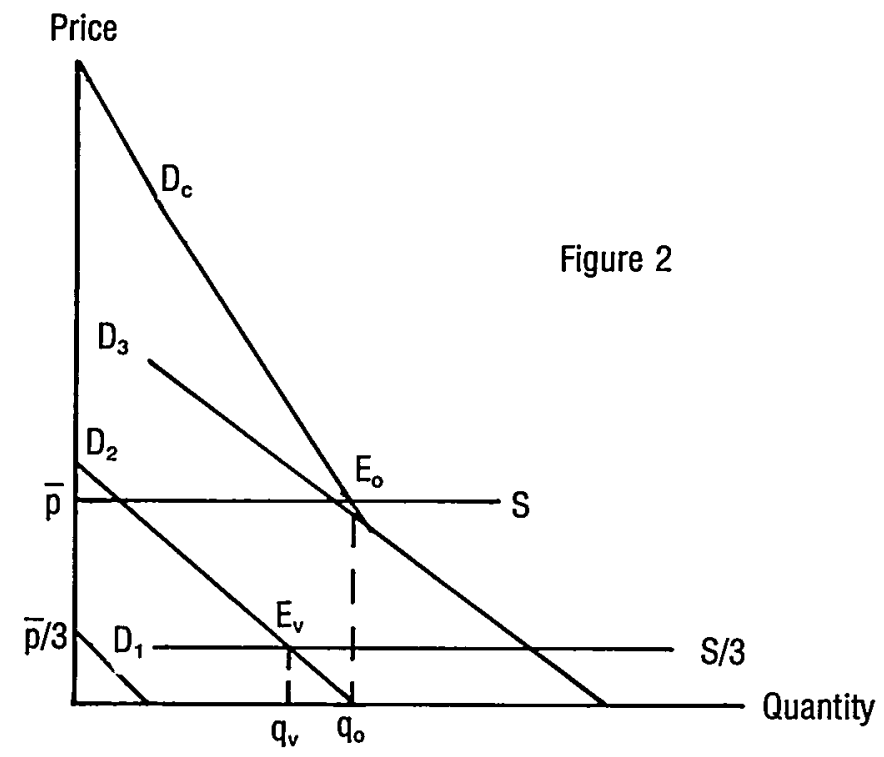


Among the individuals who desire more of a social good than is provided through the majority voting model, some may value additional output highly enough to supplement the government's direct provision. These individuals may make private contributions to chari-

This result can be proved as follows: By relaxing the non-negativity assumption, the demand curve of individual $i$ can be written (assuming that all demand curves are parallel) as

and his supply curve as

$$
p_{1}=a_{1}-b q
$$

$$
\mathrm{p}_{1}=\frac{\overline{\mathbf{p}}}{\mathrm{n}} \text {, }
$$

where $\mathbf{n}$ is the number of voters. Under the median voter rule (assuming that $\mathrm{n}$ is odd), quantity $q_{r}$ is determined by the condition that the median voter, individual $v$, is just willing to pay the marginal cost to him:

$$
a_{\mathbf{v}}-b q_{v}=\frac{\bar{p}}{n} .
$$

Solving for $q_{\mathbf{r}}$ :

$$
q_{\nabla}=\frac{a_{\nabla}-\frac{\bar{p}}{n}}{b} .
$$

Under the optimal social-goods rule, quantity $q_{0}$ is determined by the condition that the sum of the individual willingnesses to pay is equal to the social cost:

Solving for $\mathrm{q}_{0}$ :

$$
\stackrel{\mathbf{n}}{i}{ }_{i}\left(a_{1}-b q_{0}\right)=\bar{p} \text {. }
$$

$$
q_{0}=\sum_{i=1}^{n} \frac{\frac{a_{1}}{n}-\frac{\bar{p}}{n}}{b} .
$$

If the demand curves are asymmetrically skewed downward,

which implies

$$
a_{v}<\sum_{i=1}^{n} \frac{a_{1}}{n},
$$

$$
\frac{a_{\nabla}-\frac{\bar{p}}{n}}{b}<\frac{\sum_{i=1}^{\mathfrak{n}} \frac{a_{1}}{n}-\frac{\bar{p}}{n}}{b}
$$

Thus we know that

$$
\mathrm{q}_{\mathbf{r}}<\mathrm{q}_{\mathbf{r}}
$$

Now the non-negativity assumption can be added. Then, under the optimal socialgoods rule, quantity $q_{0}^{*}$ is described by the condition

$$
\sum_{i=1}^{j} \quad a_{1}-j_{b q}^{*}=\bar{p} \text {, }
$$

where $j$ is the index of the interval $\left(\frac{a_{1}}{b}<q<\frac{a_{1+1}}{b}\right)$ in which $q_{\nabla} *$ falls.

$$
\stackrel{i=1}{\Sigma}_{i=1}^{n} a_{1}-n b q_{0} *=\sum_{i=1}^{j} a_{1}-j b q_{0} *+\sum_{i=j+1}^{n} a_{1}-(n-j) b q_{0} *
$$

Since $\frac{a_{j}}{b} \leqslant q_{0} *$, we have 


\section{Artists}

table organizations that provide the particular social good. ${ }^{33}$ Because of the free-rider problem that is endemic to social goods, however, this additional private output still will not generate the optimal level of production. ${ }^{34}$

Thus, both private markets and government provision will generate less than the optimal level of output of social goods. However, a hybrid solution may remedy much of the deficiency. Recall that the median voter determines the amount of a social good to be provided by the government by equating his marginal costs and his marginal benefits. He values additional output, but not enough to pay his full share of the marginal costs. Other individuals, however, are already supple-

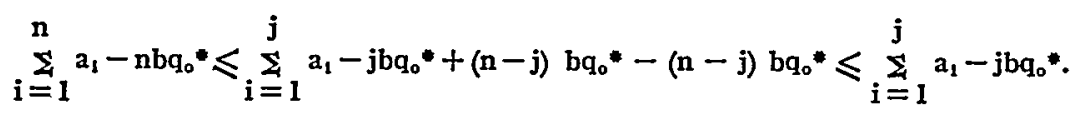

Since all demand curves slope downward, $q_{0}<q_{0} *$.

Since $\mathrm{q}_{\nabla}<\mathrm{q}_{\mathrm{o}}$, we have the desired result:

$$
\mathrm{q}_{\mathrm{r}}<\mathrm{q}_{\mathrm{o}} *
$$

The median voter rule leads to a suboptimal amount of public access to creative compositions. See Hochman \& Rodgers, The Optimal Tax Treatment of Charitable Contributions, 30 NaT'L TAX J. 1, 2 (similar model).

33. Figure 3 shows the demand, $D_{3}$, of such a person, the third voter, who will provide voluntarily $\left(q_{p}-q_{p}\right.$ ) to supplement $q_{v}$, the public access provided by the government under the median voter rule.

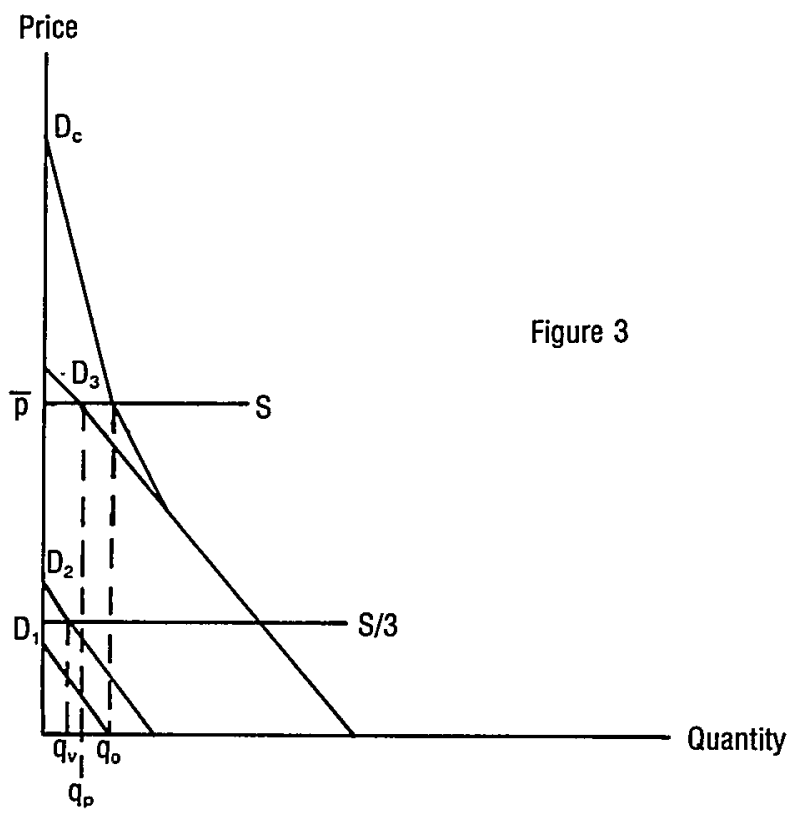

34. That is, in Figure 3, supra note 33, $q_{p}$ is less than $q_{o}$, the optimal level of output. This will be true unless $S$ is so low that it intersects $D_{c}$ and $D_{3}$ at the same $q$, in which case there is no free-rider problem because only $D_{3}$ values the good at that level of output. 
menting the government's output and paying the full cost of providing additional output. The median voter would approve a higher level of governmentally supported output if he were obligated to pay only a portion of the marginal costs of the additional output, that is, if his marginal costs were reduced. Similarly, the high-demand individuals who are contributing to increase the output would contribute more if they were not required to fund the entire cost of the additional output. If the two production mechanisms, government funding through majority vote and private provision through contributions, could be integrated, the mutual interests of the median voter and the highdemand incividuals could be fulfilled, and the deficiency in the level of output of social goods could be alleviated.

The charitable contributions deduction is such a mechanism: it combines government subsidy with individual support to increase the amount of social goods toward the optimal level. ${ }^{35}$ The median voter is offered a chance to secure additional output of social goods by paying only his share of the marginal costs necessary to induce high-demand individuals to increase their amount of contributions. ${ }^{36}$ These in-

35. The difficulties inherent in using direct provision to allocate the total level of public access among different types of creative compositions, see note 30 supra, are also remedied by the charitable contributions deduction. The deduction avoids the problems of elitism and popularism, by accommodating diverse preferences. The deduction also eliminates the political defect of direct provision, as it yields an atomistic, rather than a bureaucratic, allocation.

36. In Figure 4 , the third voter would increase his private support by $\left(q_{s}-q_{s}\right)$, if his costs for doing so were reduced to $S^{\prime}$ (due to the charitable deduction). The median voter would vote to pay $(\mathrm{S} / 3)^{\prime}$ if he were provided increased output to the level of $\mathrm{q}_{\mathrm{s}}$.

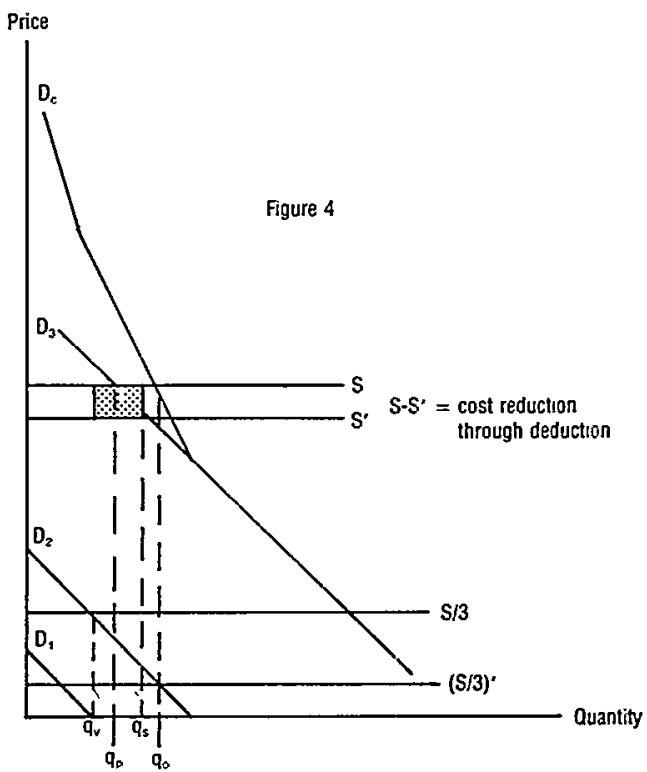


dividuals, who are already contributing the total costs of providing supplemental output, are encouraged to increase their level of contributions through the partial subsidy approved by the median voter. ${ }^{37}$

The costs imposed by the charitable contributions deduction are minimal. ${ }^{38}$ The valuation problem created by the allowance of a deduction for contributions of property does not appear troublesome. ${ }^{39}$ It appears that the revenue loss to the Treasury from the partial subsidy of charitable contributions is significantly less than the amount of resources contributed as a result of the deduction. ${ }^{40}$

Although the charitable contributions deduction may not lead to the optimal level of production of a social good, the deduction certainly increases output torward that optimum. ${ }^{41}$ Each contribution generated by a subsidy that is approved by the median voter results in a reduction in the shortfall from the optimal level of the good. Thus, the deduction provides an incentive for individuals with unsatisfied demand for public access to creative compositions to contribute such property to charitable organizations. Under current law, creators, who may have

37. Thus, in Figure 4, supra note 36, if the tax funds raised by the subsidy, $(n-1)$ $(S / n)^{\prime}\left(q_{s}-q_{v}\right)$, are greater than or equal to the amount needed to encourage giving by the $n$th voter to the level $\mathrm{q}_{\mathrm{s}},\left(\mathrm{S}-\mathrm{S}^{\prime}\right)\left(\mathrm{q}_{\mathrm{s}}-\mathrm{q}_{\mathrm{v}}\right)$, the median voter will approve the subsidy.

38. This analysis ignores the possible costs sustained by individuals who desire social goods for private consumption and are made worse off when such goods are transferred to non-cxcludable uses. See note 20 supra.

39. See 122 Cong. REc. 23,359-60 (1976) (Sen. Javits) (valuation no longer a problem); [1978] Comm'r of Internal Revenue Ann. Rep. 43 (Art Advisory Panel has made adjustments of $\$ 75$ million in $\$ 276$ million of claimed valuation in last 10 years).

40. See Feldstein \& Clotfelter, Tax Incentives and Charitable Contributions in the United States: A Microeconometric Analysis, in III FILER PAPERs, supra note 5, at 1393, 1394, 1413 (earlier studies unreliable; net incentive effects strong); Feldstein \& Taylor, The Income Tax and Charitable Contributions: Estimates and Simulations with the Treasury Tax Files, in III FILER PAPERs, supra note 5, at 1419, 1437 (strong evidence of net incentive effect); McDaniel, Study of Federal Matching Grants for Charitable Contributions, in IV FILER PAPERs, supra note 5, at 2417, 2435-43 (survey of econometric and opinion polling literature).

41. Any subsidy that is approved by the median voter and that stimulates additional contributions necessarily mitigates the deficiency in the production of a social good. That is, if any additional contribution results from the subsidy, output has been increased to $\mathbf{q}_{\mathrm{s}}$, beyond $\mathbf{q}_{\mathrm{p}}$ and toward $\mathbf{q}_{\mathrm{o}}$. See note 36 supra.

An ideal subsidy scheme would offer a different level of subsidy for contributions teading to increase public access to each different type of creative composition, depending on the relative magnitudes of shortfalls in access to each type. The charitable contribution deduction cannot be tailored to achieve that precise goal, however, because it does not depend on the type of access that is subsidized. As a result, public access to some types of compositions inevitably will be over-subsidized and public access to other types under-subsidized. The deduction also is imperfect in that it benefits contributors in proportion to their marginal tax rates and offers no subsidy to nontaxpaying or non-itemizing donors, thereby biasing the $\mathrm{mix}$ of increased public access to creative compositions toward that demanded by high-income taxpayers and exacerbating the inequality of the distribution of wealth. See Hochman \& Rodgers, supra note 32, at 7-10 (proportionality of deduction subsidies to income generates suboptimal allocation). 
the strongest demand for public access to creative compositions, are provided the least incentive to contribute. Providing these artists with an incentive to contribute their compositions would help achieve an optimal level of public access to each type of creative composition.42

\section{B. Generation of an Accurate Revelation of Preferences}

The justification for the charitable contributions deduction rests on the ability of private philanthropy to reveal information about individuals' unsatisfied preferences for social goods. To achieve an optimal production of social goods, however, two types of preferences must be revealed: the total level of demand for social goods, and the allocation of that demand among various types of social goods. The charitable contributions deduction should be structured to provide accurate information about both sets of preferences.

Claimed deductions can be interpreted as indicators of an individual's demand for increased public access to creative compositions. Because the deduction results in only a partial subsidy from the government, the individual is undertaking a philanthropic endeavor in supporting a charitable organization that provides the public with access to particular kinds of compositions.

However, a contribution that results in a net financial benefit to the taxpayer, relative to his other options, ${ }^{43}$ yields no information about his preferences for particular social goods. Assumptions about his preferences ranging from no demand to substantial demand are all equally consistent with his demonstrated behavior. ${ }^{44}$ The for-profit feature of the transaction renders it likely that the normal economic goal of profit maximization-including the minimization of transaction costsdominates any social-goods interest. ${ }^{45}$ Thus, for the charitable contri-

42. In Figure 4, supra note 36 , an artist may have demand $D_{3}$ for a particular type of composition. Providing such an artist with a deduction subsidy will shift his cost of contribution from $S$ to $S^{\prime}$ and cause him to donate $\left(q_{s}-q_{p}\right)$ of that type of good. If the same artist's demand for another type of composition is represented by $D_{1}$, no donation of that type of work will result from the subsidy.

43. The only option directly comparable to donating is selling the work at its fair market value. Other alternatives, such as holding, noncharitable giving, or bequeathing, are unpredictable and too speculative and indeterminate for a comparison. Accordingly, the benefit from selling is the standard used to define effects of contributing.

44. "In cases where the tax saving is so large, it is not clear how much charitable motivation actually remains. It appears that the Government, in fact, is almost the sole contributor to the charity." H.R. REP. No. 413, 91st Cong., lst Sess. 54, reprinted in [1969] U.S. Code Cong. \& AD. News 1700.

45. It is generally assumed that an individual making a profitable transaction is not particularly interested in the characteristics of the other party to the transaction cxcept insofar as the transaction itself is affected (as, for example, by the reliability of the other 
butions deduction to be a useful indicator of individual preferences for social goods, the deduction must never enable a taxpayer to profit more from contributing his property than he could have benefited from selling it.

\section{Consideration of Horizontal Equity and Economic Efficiency}

General principles of tax policy have evolved to mitigate undesirable effects of individual provisions of the Internal Revenue Code on the operation of the income tax system as a whole. These principles should shape the specific design of the charitable contributions subsidy. One such principle is that individuals in similar financial circumstances should be treated similarly by the tax system. ${ }^{40}$ This concept is termed "horizontal equity." Another concern is that tax provisions should exert a neutral effect on economic decisions by individuals and firms operating in competitive markets. ${ }^{47}$ Any influence of the tax system on those decisions generates a misallocation of resources by interfering with the capacity of a competitive pricing system to direct resources to their most productive uses. ${ }^{48}$

These principles require that contributions of creative compositions by creators and collectors should be treated as similarly as possible, irrespective of the difference in the ways in which the contributed compositions were acquired. The equity concern is simple: two individuals with similar incomes contributing similar property to similar recipients are for tax purposes similarly situated; the fact that one created his property, while the other acquired it from someone else, should not be deemed relevant. Efficiency considerations also militate against treating contributions of creator-held property differently from those of collector-held property, for fear that the creator may be influenced to devote fewer of his resources to holding personally created property and more to collecting, or investing, than would be optimal.

Moreover, for reasons of both equity and efficiency, contributions of cash and contributions of property should be treated as similarly as possible, inasmuch as the relevant fact for tax purposes is the value, not

party). The individual's utility is assumed to be independent of the other party's level of consumption. When an individual does not benefit financially, it is more likely that his utility in some way depends on the consumption of the other party.

46. See R. MusGrave, supra note 18 , at 160 .

47. This does not imply that when markets are not functioning perfectly, as, for example, when there is a market failure arising from the free-rider problem, they should not be assisted in improving resource allocation. Nor does it imply that suboptimal allocations will never be preferred to optimal allocations for other-for example, distributional-reasons.

48. See R. Dorfman, supra note 21 , at 196-215. 
the form, of the contribution. Equity requires that individuals with similar incomes who donate similarly valued property receive similar treatment by the tax system. Furthermore, the efficiency consideration suggests that different treatment for gifts of cash and contributions of property would lead to undesirable distortions in the decisions of individuals to acquire and dispose of their assets. ${ }^{49}$

\section{Proposal for Legislative Change}

Proposed legislation should evolve from consideration of the competing social objectives developed above. Amendment of the Internal Revenue Code to provide creators a quasi-capital gains option would reasonably satisfy these goals.

\section{A. Reconciling the Policy Objectives}

The four policy objectives-provision of an incentive for creators to donate their compositions; assurance that such donation not be financially preferable to sale; equal treatment of creators and collectors; and equal treatment of gifts of cash and contributions of propertycannot be achieved simultaneously through legislation affecting only the tax treatment of charitable contributions by creators. Collectors are currently provided a fair market value deduction for gifts of related-use tangible personal property that qualifies for long-term capital gains treatment. ${ }^{50}$ Equal treatment for creators could enable them to benefit

49. Because the set of all creative compositions is not a single homogeneous type of good, the amount of access to different types of compositions should reflect individual preferences. In that way, the level of public access to each type of composition will be optimal. For the charitable contributions deduction to be useful as an indicator of the distribution of individuals' social goods preferences among goods, the deduction subsidy cannot bias individuals' decisions as to how much to contribute to each potential donee by providing differential subsidies. As an example of such a bias under present law, donations of related-use tangible personal property are treated more favorably than contributions of unrelated-use tangible personal property. See I.R.C. $\$ 170(e)(1)$. Thus, an individual may be led to donate a painting to the Museum of Modern Art even though he prefers the work of the Red Cross, because of the preferential treatment accorded related-use property donations. Therefore, contributions of various kinds of property and cash should be treated similarly.

One minor justification can be offered for some differential treatment of cash and property contributions. Creators and collectors donating creative compositions to charitable organizations may be more informed generally about the quality differences among works of art and artistic institutions than are members of the general public who support organizations with cash donations. Therefore, it may be warranted to offer a greater subsidy to contributors of property than to cash donors, in order to weigh revealed preferences for social goods in favor of more aware donors. The information-provision approach to contributions, see note 20 supra, also may justify the preference for donations of property. Both of these arguments, however, are vulnerable to the "elitism" criticism of direct provision. See note 30 supra.

50. I.R.C. $\$ \S 170(a)(1), 170(e)(1)$. 
more from the donation of such property than from its sale. ${ }^{51}$ Therefore, it is impossible both to establish parity between creators and collectors and to ensure that gifts by creators will be less profitable than sales, without changing the tax treatment of donations by collectors. The policy that creators be treated similarly to collectors is also in conflict with the goal that creators' gifts of cash be treated similarly to creators' donations of property: under current law there is a disparity in the treatment of the two types of contributions for collectors. ${ }^{52}$ Lastly, identical treatment for cash and property donations conflicts with the goal of providing creators with an incentive to donate their compositions, since such an incentive would be increased by more favorable treatment of property donations.

The issues of the tax treatment of charitable contributions by collectors and the taxation at ordinary income rates of sales by creators implicate factors that render changes in this area politically infeasible. This constraint makes it impossible to satisfy all four objectives completely. Nevertheless, legislative change must reflect the optimal accommodation of these goals. The policies that creators be provided with an incentive to contribute their compositions and that such an incentive never make contribution more lucrative than sale are mandated by the social-good analysis above. Without a contributions subsidy, the level of public access to creative compositions is seriously deficient. However, a deduction rendering gifts more profitable than sales for any individual destroys the usefulness of the preference revelation mechanism by encouraging and subsidizing donations that do not necessarily represent underlying demand for public access to compositions. Therefore, proposed legislation should satisfy both of these policies. ${ }^{53}$

51. Parity between creators and collectors would violate the rule that $\pi_{s}>\pi_{\varepsilon}$ for creators, because creators are taxed on sales at ordinary income rates, while collectors are not. See note 7 supra.

52. See note 8 supra.

53. Two recent types of legislative proposals to restore an incentive for charitable contributions by creators of creative compositions would allow creators to benefit more from contributing their compositions than from selling them, thereby violating the requirement that the government not reward solely self-interested motivations. A return to the fair market value deduction, see note 7 supra, has been proposed in recent bills. See, e.g., H.R. 10429, 95th Cong., 2d Sess. (1978); H.R. 1739, 95th Cong., Ist Sess. (1977); H.R. 2046, 95th Cong., Ist Sess. (1977). No action was taken on any of these bills.

The second type of proposal would allow a deduction in the amount of basis plus $75 \%$ of unrealized appreciation. This proposal typically includes a limitation that deductions for charitable contributions of creative compositions may be taken for amounts not greater than income from the sale of creative compositions. A creator in the $70 \%$ bracket on unearned income who paints a painting that cost $\$ 100$ in materials and has a market value of $\$ 1500$ is in the following situation: if he sells the painting, he earns $\$ 1500$ before taxes on an investment of $\$ 100$, for a taxable income of $\$ 1400$, upon which he pays a $50 \%$ tax, thus netting him $\$ 700$ after taxes. By contributing the painting, he 
The principles establishing similar tax treatment for cash and property contributions and parity between creators and collectors must be compromised. Any compromise will both provide donors of appreciated property with some advantage over contributors of cash and to some extent favor collectors over creators. Nevertheless, proposed legislation should accommodate these principles to the extent possible, given the constraints of the other two policy goals and of other provisions in the Code. ${ }^{54}$

\section{B. A Legislative Proposal}

The unfavorable treatment accorded contributions of creator-held compositions stems from the characterization of these works as ordinary income property, rather than capital gains property. Yet much of the value of creator-held appreciated property derives from a phenomenon more easily analogized to the accrual of capital gains than to the earning of ordinary income. A deduction provision that provided capital gains treatment for the portion of unrealized appreciation attributable to long-term investment and ordinary income treatment for the amount derived from personal effort would be grounded more soundly in tax theory than would other recent legislative proposals. ${ }^{55}$

is entitled to a deduction of the $\$ 100$ basis plus $75 \%$ of the $\$ 1400$ appreciation, for a total of $\$ 1150$. This deduction reduces his taxes (assuming he has other creative and investment income) by $\$ 805(.7 \times \$ 1150)$, earning him a net gain of $\$ 705(\$ 805-\$ 100$ cost) . Thus, this high-income artist has obtained a $\$ 5$ benefit by contributing instead of selling his work. In general, a gift would be more profitable than a sale whenever $\mathrm{m}>\frac{\mathrm{C}+.5 \mathrm{~A}}{\mathrm{C}+.75 \mathrm{~A}}$ (see note 7 supra for explanation of notation). As $\mathrm{C} / \mathrm{A}$ approaches zero, this requirement simplifies to $\mathrm{m}>2 / 3$. Under no circumstances when $\mathrm{m}<2 / 3$ can $\pi_{s}>\pi_{s}$. Furthermore, the greater $\mathrm{C} / \mathrm{A}$ is, the greater $\mathrm{m}$ must be for $\pi_{\mathrm{g}}>\pi_{\mathrm{s}}$. If $\mathrm{m}=.7$, then $\pi_{\mathrm{g}}>\pi_{\mathrm{s}}$ only when $\mathrm{C} / \mathrm{A}<1 / 12 .\left(\pi_{\mathrm{g}}>\pi_{\mathrm{s}}\right.$ only if $\frac{.75 \mathrm{~m}-.5}{1-\mathrm{m}}>\mathrm{C} / \mathrm{A}$. $)$

Two bills provided for a deduction of basis plus $75 \%$ of appreciation: S. 1435, 94th Cong., Ist Sess. (1975) and H.R. 6057, 94th Cong., Ist Sess. (1975). No action was taken on either bill.

54. One recent proposal would provide a tax credit of $30 \%$ of market value, while limiting the credit to the amount of tax imposed on creative-source income. See, e.g., H.R. 10445, 95th Cong., 2d Sess. (1978); S. 1384, 95th Cong., Ist Sess. (1977); H.R. 439, 95th Cong., lst Sess. (1977). A floor amendment to the Tax Reform Act of 1976 providing a credit passed the Senate but was dropped in conference and did not become law. See 122 Cong. Rec. 25,631 (1976); H. Conf. ReP. No. 1515, 94th Cong., 2d Sess. 452 (1976). This credit proposal violates the goal of consistent treatment of individuals by retaining a deduction for gifts of collector-held property but providing a credit for contributions of creator-held property. The credit scheme causes distortions, such as providing an incentive to creators to contribute even if they do not itemize deductions, but providing no subsidy for donations by other non-itemizing taxpayers. These distortions are so great that the credit proposal can be ruled out on the basis of the similar treatment goal alone.

55. The individual classification of business assets as capital or non-capital assets upon 
The policy goals discussed above generally would be satisfied by amending the Internal Revenue Code to allow creators the option of having compositions valued upon completion and paying a tax at ordinary income rates at the time of gift on the difference between the fair market value at the time of completion and the basis, in return for allowing them a portion of appreciation to be deducted upon gift. Under this quasi-capital gains proposal, a creator exercising the option and contributing his composition to a charitable organization would be entitled to deduct at the time of contribution the full fair market value of the property, less forty percent ${ }^{56}$ of the unrealized appreciation that accrued between the time of contribution and the time of completion. ${ }^{57}$

The proposed option would restore an incentive for creators to contribute their creative compositions to charitable organizations. ${ }^{58}$

the sale of a business is roughly analogous. See Williams v. McGowan, 152 F.2d 570 (2d Cir. 1955).

Two recent proposals rely on arbitrary formulas that bear no apparent relation to the present tax treatment of collectors. The first proposal would allow a fixed percentage deduction in the amount of basis plus $50 \%$ of unrealized appreciation. See, e.g., H.R. 7577, 92d Cong., lst Sess., 118 Cong. REc. 36,636-37 (1972) (Senate version only). The second proposal would allow a graduated percentage of appreciation deduction based on the donor's marginal tax bracket. A sliding percentage of appreciation would be deductible, and the scale could be graduated to ensure that sale always would be preferable financially to contribution. In testimony before the Ways and Means Committee in 1973, the Authors League of America supported such a graduated deduction. See 1973 HEARINGs, supra note 2, at 6112-13.

56. Under current law, $60 \%$ of capital gains income is excluded from taxation. I.R.C. $\S 1202$ (a). Under certain circumstances, the reduction in the allowable deduction would have to be by an amount greater than $40 \%$ of the post-completion appreciation. See note 59 infra.

57. Under the proposal, a creator could elect to claim a deduction for a charitable contribution of his creative compositions based on the fair market value, less $40 \%$ of the unrealized appreciation that accrued after completion of the composition. In order to claim the optional deduction, the creator would be required to pay income tax at ordinary income rates on the difference between the fair market value of the composition immediately upon its completion and its basis. The creator could be required to have the composition valued upon completion to preserve his ability to claim the optional deduction should he ever contribute the work to a charitable organization. However, for administrative convenience and ease of compliance, a mechanical allocation rule could be provided. For example, the ordinary income component of the appreciation could be treated as having accrued over a one-year period and the total appreciation could be allocated between ordinary income and capital gains on a pro rata time basis. Such a rule could be made optional to allow the taxpayer to elect to submit proof of earlier valuation in lieu of mechanical allocation.

58. Beginning with the example in note 53 supra, add the assumption that the painting was worth $\$ 400$ when it was completed. Under present law, the creator loses $\$ 30$ by contributing his painting $\left(\pi_{g}=-\$ 100+.7(\$ 100)\right)$. Under the option, however, the creator pays a tax of $\$ 150$ on the appreciation attributable to his personal efforts $(.5(\$ 400-\$ 100))$ and receives a deduction upon gift of $\$ 1060(\$ 1500-.4(\$ 1500-\$ 400))$ for a tax benefit of $\$ 742(.7 \times \$ 1060)$. Thus, his net gain totals $\$ 492(\$ 742-\$ 100-\$ 150)$. Generally, $\pi_{g}=A_{1}(m-.5)+.6 \mathrm{~mA}_{3}-\mathrm{C}(\mathrm{I}-\mathrm{m})$, where $\mathrm{A}_{1}$ is the difference between fair market value at time of completion and basis, and $A_{2}$ is the difference between fair mar- 
At the same time, it would be impossible for a creator to benefit more from contributing a composition than from selling it. ${ }^{50}$ The option also would reduce the disparity between the treatment of gifts of property and of cash donations by taxing a portion of the appreciation at ordinary income rates as a condition for claiming a deduction for the remainder of the appreciation. ${ }^{60}$ Finally, the proposal would roughly equalize the treatment of creators and collectors. By allowing creators a deduction that accounts for unrealized appreciation, while taxing them on the ordinary income appreciation, the treatment of creators would match the tax situation of collectors. ${ }^{61}$

ket value at time of gift and market value at time of completion. The examples and formulas in this section assume a taxpayer in the maximum tax brackets of $50 \%$ on earned income and $70 \%$ on unearned income. Different configurations of earned and unearned income will lead to varying results.

59. This can be proved as follows: $\pi_{g}<\pi_{s}$, because $\pi_{\varepsilon}=(\mathrm{m}-.5) \mathrm{A}_{1}+.6 \mathrm{~mA}_{2}-\mathrm{C}(\mathrm{l}-$ $\mathrm{m})$, which is always less than $\pi_{\mathrm{s}}=.5 \mathrm{~A}_{1}+.5 \mathrm{~A}_{2}$, because $(\mathrm{m}-.5) \mathrm{A}_{1}<.5 \mathrm{~A}_{1}, .6 \mathrm{~mA} \mathrm{~A}_{2}<.5 \mathrm{~A}_{2}$ and $C(1-m)>0$, whenever $.5 \leqslant \mathrm{~m} \leqslant .7$, and $C, A_{1}$, and $A_{2}$ are all positive.

For high-income taxpayers with little earned income relative to unearned income, it is possible for the marginal tax rate on earned income to exceed $50 \%$ in spite of the maximum tax provision, I.R.C. $\$ 1348$. See Sunley, The Maximum Tax on Earned Income, 27 NAT'L TAX J. 543, 544-45 (1974) (effects of maximum tax limited by rule stacking earned income before unearned income). In this case, the formulas above are inapplicable, and the percentage of $\mathrm{A}_{2}$ allowed to be deducted under the proposal must be reduced to ensure that $\pi_{5}<\pi_{s}$. Therefore, the taxpayer must first determine his marginal tax rate without benefit of the deduction; if the marginal rate exceeds $62 \%$-but his carned income alone would not put him in the $70 \%$ bracket-the deductible amount of the contribution must be reduced by a percentage of $A_{2}$ that increases with the marginal rate for the tax brackets between .62 and .70 as follows:

$\begin{array}{cc}\text { If } \mathrm{m}= & \text { Then deduction is reduced by } \\ .63 & .42 \\ .64 & .44 \\ .68 & .53 \\ .70 & .58 \text { of } \mathrm{A}_{2} \text {. }\end{array}$

Only if $\mathrm{m} \leqslant .62$, or if $\mathrm{m}=.70$ even without considering any unearned income, should the taxpayer reduce his deduction by only $40 \%$ of $A_{2}$.

60. The proposed treatment of the ordinary income portion of the appreciation is to $\operatorname{tax}$ this "earned income" at $50 \%$ and to allow a deduction at $70 \%$. Thus, the net effect of the proposal is to allow a net tax benefit for the appreciation attributable to ordinary income. This treatment can be distinguished from the nondeductibility of charitable contributions of personal services under Treas. Reg. $\$ 1.170 \mathrm{~A}-\mathrm{I}(\mathrm{g})(1972)$. The donation of creative compositions constitutes the relinquishment of ownership rights to property, while the donation of services does not entail a transfer of any property interest. See Goss v. Commissioner, 59 T.C. 594, 596 (1973) (donation of completed manuscript different from donation of services and blank paper because donor maintained physical ownership over property before donation).

61. A collector earns money in some manner and pays income tax on it when it is earned. He then invests a portion of his after-tax income in creative property. If the property appreciates, he may sell it and pay a capital gains tax on his income (assuming he holds it for at least one year), he may contribute the property to a related-use donee organization and receive a deduction of the work's fair market value, or he may contribute it to an unrelated-use organization and deduct the fair market value less $40 \%$ of the unrealized appreciation. But see note 59 supra. The proposal in this Note parallels 
This separation of the unrealized appreciation into an ordinary income portion and a capital gains portion represents an application of the familiar capital asset concept. The division maintains the general distinction between ordinary income property as property producing business income and capital gains property as property generating investment income. ${ }^{62}$ It does so by treating gains in the value of the composition arising from the creator's personal efforts as ordinary income, while treating subsequent appreciation arising from the creator's investment in his own composition after its completion similarly to capital gains. The proposed option satisfies the primary objectives for statutory tax treatment of creator-held creative compositions while satisfying to the extent possible other goals of tax policy.

the last situation of the collector as closely as possible. Both pay an ordinary income tax on the income attributable to their personal efforts; both receive a deduction upon gift of market value less $40 \%$ of investment appreciation. The proposed treatment for creators does not match the present taxation of collectors who sell their work or contribute it to a related-use organization. The latter provision is inconsistent with the requirement that gifts not be financially advantageous relative to sales. See pp. 160-61 supra. Although the analysis of creators' gifts could be applied similarly to gifts of other types of property and to gifts of other donors, and greater parity could be established, the issue is beyond the scope of this Note because of the number of additional complex issues involved. In addition, an argument can be made for capital gains treatment of sales of creator-held compositions, see note 62 infra, but, because the issue requires lengthy discussion, it is not considered in this Note.

62. See L. Seltzer, The Nature and Tax Treatment of Gapital Gains and Losses 3 (1951), reprinted in B. Bitrker \& L. Stone, Federal Income, Estate, and Gift Taxation 490 (1972) (distinguishing capital gains from ordinary income); Surrey, Definitional Problems in Capital Gains Taxation, 69 HARv. L. Rev. 985 (1956) (same); Miller, Capital Gains Treatment of the Fruits of Personal Effort: Before and Under the 1954 Code, 64 YALE L.J. 1 (1954) (taxation of gains from personal effort). 